\title{
Long-term Tillage and Nitrogen Fertilization Effects on Soil Properties and Crop Yields
}

\author{
Muhajir Utomo, Irwan Sukri Banuwa, Henrie Buchari, Yunita Anggraini and Berthiria \\ Soil Science Division, Agrotechnology Department, Faculty of Agriculture, University of Lampung, \\ Jl. Sumantri Brojonegoro, Bandar Lampung, 35145, Indonesia, phonelfax: +62-721-781822, \\ "email: mutomo2011@gmail.com, "e-mail: irwanbanuwa@yahoo.com
}

Received 8 March 2013 / accepted 2 May 2013

\begin{abstract}
The impact of agricultural intensification on soil degradation now is occurring in tropical countries. The objective of this study was to determine the effect of long-term tillage and $\mathrm{N}$ fertilization on soil properties and crop yields in corn-soybean rotation. This long-term study which initiated since 1987 was carried out on a Typic Fragiudult soil at

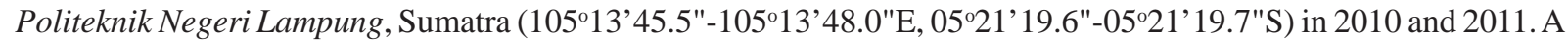
factorial experiment was arranged in a randomized block design with four replications. The first factor was tillage system namely intensive tillage (IT) and conservation tillage (CT) which consisted of minimum tillage (MT) and notillage (NT); while the second factor was N fertilization with rates of 0,100 and $200 \mathrm{~kg} \mathrm{~N}^{-1}$ applied for corn, and 0, 25 , and $50 \mathrm{~kg} \mathrm{~N} \mathrm{ha}^{-1}$ for soybean. The results showed that bulk density and soil strength at upper layer after 24 years of cropping were similar among treatments, but the soil strength under IT at 50-60 cm depth was $28.2 \%$ higher $(\mathrm{p}<0.05)$ than NT. Soil moisture and temperature under CT at $0-5 \mathrm{~cm}$ depth were respectively $38.1 \%$ and $4.5 \%$ higher $(\mathrm{p}<0.05)$ than IT. High $\mathrm{N}$ rate decreased soil $\mathrm{pH}$ at $0-20 \mathrm{~cm}$ depth as much as $10 \%$, but increased total soil $\mathrm{N}$ at $0-5 \mathrm{~cm}$ depth as much as $19 \%(\mathrm{p}<0.05)$. At $0-10 \mathrm{~cm}$ depth, MT with no $\mathrm{N}$ had highest exchangeable $\mathrm{K}$, while IT with medium $\mathrm{N}$ rate had the lowest $(\mathrm{p}<0.05)$. At $0-5 \mathrm{~cm}$ depth, MT with no $\mathrm{N}$ had highest exchangeable $\mathrm{Ca}$, but it had the lowest $(\mathrm{p}<0.05)$ if combined with higher $\mathrm{N}$ rate. Microbial biomass $\mathrm{C}$ throughout the growing season for $\mathrm{NT}$ was consistently highest and it was $14.4 \%$ higher $(\mathrm{p}<0.05)$ than IT. Compared to IT, Ap horizon of CT after 24 years of cropping was deeper, with larger soil structure and more abundance macro pores. Soybean and corn yields for long-term CT were $64.3 \%$ and $31.8 \%$ higher $(\mathrm{p}<0.05)$ than IT, respectively. Corn yield for long-term $\mathrm{N}$ with rate of $100 \mathrm{~kg} \mathrm{~N}^{-1}$ was $36.4 \%$ higher $(\mathrm{p}<0.05)$ than without $\mathrm{N}$.
\end{abstract}

Keywords: Conservation tillage, crop yields, $\mathrm{N}$ fertilization, soil properties

\section{INTRODUCTION}

The impact of agricultural intensification due to the need of food on soil degradation now is occurring in tropical countries where the resources are scarce, fragile, and stressed by a harsh climate. Conversion to recommend soil management practices such as conservation tillage (CT) can reverse the degradation trend and lead to a gradual improvement in soil quality (Lal 2007). Conservation tillage is any tillage or cropland system that leaves at least 30\% plant residues as mulch covering soil surface (Lal 1989; Lal 1997; Utomo 2004). In Indonesia CT that includes minimum tillage (MT) and no-tillage (NT) of corn and soybean now are increasingly adopted by farmers because of lower production costs compared to intensive tillage (Utomo 2004).

J Trop Soils, Vol. 18, No. 2, 2013: 131-139 ISSN 0852-257X
Plant residues from previous crop season which are used as mulch is important in CT practices. This is not only because its effective ness in reducing soil erosion, but also in converting the substrate to microbial biomass carbon (Wright and Hons 2004; Smith and Collins 2007; Utomo et al. 2010), and in increasing soil organic carbon that has influence on soil physical, chemical and biological properties especially in surface horizon (Stockfisch et al. 1999; Fernandez et al. 2007; Thomas et al. 2007; Brady and Weil, 2008; Quintero 2009; Utomo et al. 2012). In long-term period, shifting from intensive tillage (IT) to conservation tillage (CT), therefore, can promote better soil property.

However, numerous experiments on soil properties between NT and IT performed different results, depending on in situ condition and period of measurement (Fengyun et al. 2011). A classic study on long-term NT in Kentucky, USA, showed that after 10 years of continuous NT corn production, there were no deterioration of soil physical properties and higher soil moisture under NT corn compared 
to IT (Blevins et al. 1983). While in chemical properties, when high $\mathrm{N}$ fertilizer rates were used, the rapid acidification of the soil surface under longterm NT was observed, exchangeable $\mathrm{K}$ and $\mathrm{Ca}$ decreased with depth (Blevins and Frye 1993). Recent studies confirmed that long-term continuous NT increased SOC and improved soil physical properties (Quintero 2009; Blanco-Canqui et al. 2010). Study on Holdrege silt loam (fine-silty, mixed, mesic Typic Argiustolls) in Nebraska had shown that after 27 years of cropping, there are differences in soil chemical properties between IT and NT at some depths (Tarkalson et al. 2006).

In Indonesia however, there are no recorded data on soil property changes as influenced by longterm management practices. The study was undertaken to determine the effect of long-term (23 and 24 years) conservation tillage and $\mathrm{N}$ fertilization on soil properties and crop yields in a corn-soybean rotation system.

\section{MATERIALS AND METHODS}

\section{Long-term Experiment Site History}

This field study was conducted in 2010 and 2011 at the experiment farm of Politeknik Negeri Lampung, Sumatra, Indonesia. The plot site is located at $105^{\circ} 13^{\prime} 45.5^{\prime \prime}-105^{\circ} 13^{\prime} 48.0^{\prime \prime} \mathrm{E}, 05^{\circ} 21^{\prime} 19.6^{\prime \prime}$ $05^{\circ} 21^{\prime} 19.7^{\prime \prime} \mathrm{S}$ with elevation from sea level is 122 $\mathrm{m}$. As part of long-term conservation tillage experiment which initiated in 1987, this study was carried out on a Typic Fragiudult soil with the slope ranged from 6 to 9\% (Utomo et al. 1989; Utomo et al. 2010). Due to increasing soil compaction within $5 \mathrm{~cm}$ depth, all plots of CT were plowed after 10 years of cropping (1997) and after 15 years of cropping (2002). In fact, there was a significant acidifying effect of continuous cropping after 14 years. To avoid further acidification, therefore, all plots in 2003 were limed with $4 \mathrm{Mg} \mathrm{ha}^{-1}$ of $\mathrm{CaCO}_{3}$ (Utomo 2004; Utomo et al. 2010).

\section{Methods and Field Procedures}

A factorial experiment of soybean-corn rotation was arranged in a randomized block design with four replications. The first factor was tillage treatment, namely intensive tillage (IT), minimum tillage (MT) and no-tillage (NT); while the second factor was nitrogen treatment with rates of 0,100 and $200 \mathrm{~kg} \mathrm{~N} \mathrm{ha}^{-1}$ for corn, while 0,25 and $50 \mathrm{~kg} \mathrm{~N}$ $\mathrm{ha}^{-1}$ for soybean. Plot size of this long-term experiment was four by six meters (Utomo et al. 1989). The cereal-legume-fallow rotation sequences were set each year. Soybean [Soya max
(L.) Merr.] variety Tanggamus was planted at spacing $20 \times 25 \mathrm{~cm}$ on May 10, 2010; while hybrid corn (Zea mays L.) variety Pioneer 21 was planted at $3-5 \mathrm{~cm}$ depth at spacing of $75 \times 25 \mathrm{~cm}$ on January 9, 2011.

Prior to soybean crop season in 2010, plot land was covered with mixture of broadleaf weeds and alang-alang (Imperata cylindrica). In CT plots, those weeds were sprayed with glyphosate of 4.8 $\mathrm{L}$ a.i. ha ${ }^{-1}$ and mixed with Rhodiamine $1.0 \mathrm{~L} \mathrm{ha}^{-1}$. Similar weed treatment was also executed prior to corn season in 2011. In CT system, all dead weed and previous crop residues were used for mulch covering the soil surface, while in IT system, all weeds and previous crop residues were removed from the plots. In no-tillage (NT) system, the soil was undisturbed except slit for planting the seed; while minimum (MT) system, the soil was slightly plowed at $0-5 \mathrm{~cm}$ depth. In contrast to CT system, the soil was plowed twice at $0-20 \mathrm{~cm}$ depth. Nitrogen source for the $\mathrm{N}$ treatment was Urea $46 \% \mathrm{~N}$. Nitrogen fertilizer application was applied as hand banding in the row close to the crop. A week after planting, $\mathrm{P}$ and $\mathrm{K}$ fertilizers at rates of $100 \mathrm{~kg}$ SP$18 \mathrm{ha}^{-1}$ and $100 \mathrm{~kg} \mathrm{KCl} \mathrm{ha}^{-1}$ were applied as basal fertilizers, respectively (Utomo et al. 2010).

Soil samples for selected soil physical properties were taken after corn harvest in 2011. Soil bulk density was determined by the core method (Blake and Hartge 1986) at depths of 0-5, 5-10 and a 10$20 \mathrm{~cm}$ depth, while total porosity was calculated from bulk density and particle density. Soil strength (penetration resistance) was measured at the depths of 0-2.5, 2.5-10, 10-20, 20-30, 30-40, 40-50, 50-60 $\mathrm{cm}$, respectively using a hand-pushed penetrometer (Eijkelkamp Agrisearch Equipment). Soil moisture and soil temperature at $0-5 \mathrm{~cm}$ depth were measured using soil moisture and soil temperature tester.

Soil samples for selected soil chemical properties were taken at depths of $0-5 \mathrm{~cm}, 5-10 \mathrm{~cm}$ and $10-20 \mathrm{~cm}$ prior to soybean planting time in 2010 . Those included soil pH (1:2.5), total soil N (macroKjeldahl), and exchangeable $\mathrm{K}$ and $\mathrm{Ca}\left(\mathrm{NH}_{4} \mathrm{OAc}\right.$, AAS). The reference site adjacent to the plots which naturally covered by alang-alang (Imperata cylindrica) and similar to the initial condition of the plots was sampled at depths of 0-5, 5-10 and 10-20 $\mathrm{cm}$ (Table 1). Microbial biomass $\mathrm{C}$ which was sampled at depth of $0-20 \mathrm{~cm}$ throughout the corn season was determined using the chloroform fumigation-incubation method.

For soil morphological characteristics after 24 years of cropping (1987-2011), representative of micro soil pedons were selected only on plot of longterm tillage systems (IT, MT and NT) combined 
Table1 1. Soil chemical characteristic at reference site prior to soybean planting, 2010.

\begin{tabular}{cccccccccc}
\hline $\begin{array}{l}\text { Depth } \\
(\mathrm{cm})\end{array}$ & \multicolumn{2}{c}{$\mathrm{pH}$} & $\begin{array}{c}\text { Organic C } \\
\left(\mathrm{g} \mathrm{kg}^{-1}\right)\end{array}$ & $\begin{array}{c}\text { Organic } \mathrm{N} \\
\left(\mathrm{g} \mathrm{kg}_{2} \mathrm{O}\right.\end{array}$ & $\mathrm{KCl}$ & $\begin{array}{c}\mathrm{P} \\
\left(\mathrm{mg} \mathrm{kg}^{-1}\right)\end{array}$ & $\begin{array}{c}\mathrm{Ca} \\
\ldots \ldots \ldots \ldots \ldots \ldots . .\end{array}$ & $\begin{array}{c}\mathrm{Mg} \\
\left(\mathrm{C} \mathrm{mole} \mathrm{kg}^{-1}\right) \ldots \ldots \ldots \ldots \ldots \ldots \ldots . . . \ldots\end{array}$ \\
\hline $0-5$ & 6.0 & 5.2 & 13.6 & 1.4 & 4.2 & 7.82 & 2.74 & 0.97 & 0.66 \\
$5-10$ & 5.9 & 5.0 & 19.4 & 1.8 & 4.4 & 7.36 & 2.38 & 0.79 & 0.52 \\
$10-20$ & 5.9 & 5.1 & 17.6 & 1.7 & 4.2 & 6.78 & 2.02 & 0.70 & 0.55 \\
\hline
\end{tabular}

with highest $\mathrm{N}$ rate treatments 50 or $200 \mathrm{~kg} \mathrm{~N}$ $\left.\mathrm{ha}^{-1}\right)$. To assess soil morphological characteristics after 24 years of cropping, the micro soil pedons with depth of around $50 \mathrm{~cm}$ was taken after corn harvest in 2011.

Soybean and corn grains were harvested on July 2010 and February 2012 from $1 \mathrm{~m}^{2}$ and $8.5 \mathrm{~m}^{2}$ in the center of each plot, respectively. Soybean yield value was computed on $12 \%$ grain moisture basis, while corn yield value was on $14 \%$ grain moisture basis.

\section{Statistical Analysis}

Statistical analysis of the data was run using the Statistical Analysis System package (SAS Institute 2003). The mean separations among treatments were obtained by honest significant difference (HSD 0.05).

\section{RESULTS AND DISCUSSION}

\section{Soil Bulk Density and Soil Strength}

Soil bulk density is one of the most common variables used to assess soil physical properties, which influences total soil porosity, movement of water and nutrient and the penetration resistance of root (Fengyun et al. 2011; Mallory et al. 2011). Different from reported by Singh and Kaur (2012), soil bulk densities in this long-term experiment at depths of 0-5 and 5-10 $\mathrm{cm}$ were not affected either by long-term tillage or by $\mathrm{N}$ fertilization treatments. No response of bulk density to the treatments was also reflected on total soil porosity parameter. In fact, the different results among researchers on bulk density studies are very much depending on in situ condition and period of measurement (Fengyun et al. 2011). Soil moisture during sampling date was relatively moist and was not significantly difference among treatments (unpublished data). The average of bulk density and porosity of long-term $\mathrm{CT}$ at $0-10 \mathrm{~cm}$ depth were $1.08 \mathrm{Mg} \mathrm{m}^{-3}$ and $59.3 \%$, respectively.

Soil strength is the property of soil that can limit root penetration (Brady and Weil, 2008). As those of soil bulk density and porosity, the soil strength at

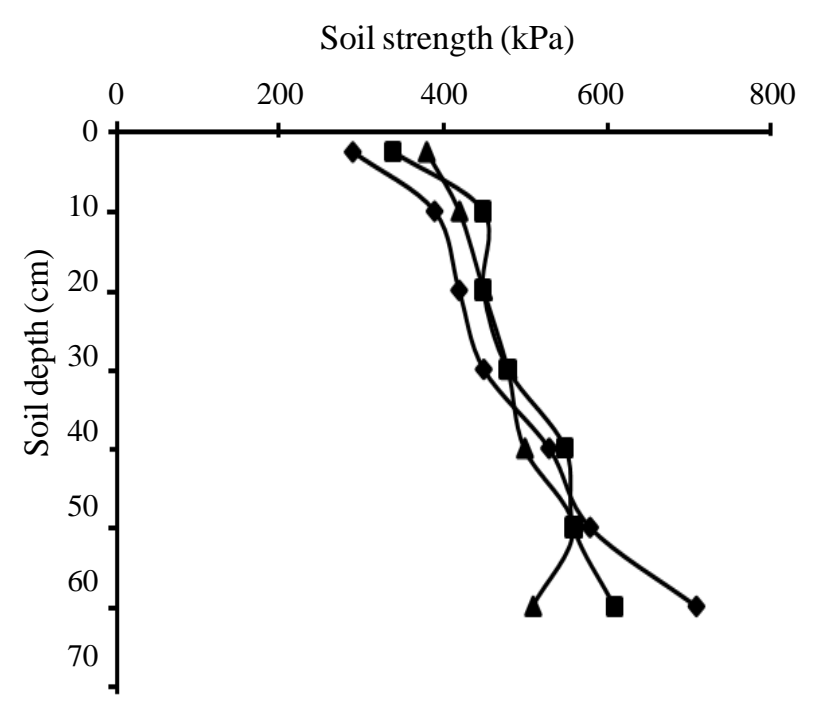

Figure 1. Soil strength after 23 years of cropping (1987-2010) as affected by tillage system at $0-60 \mathrm{~cm}$ depth; intensive tillage $(\bullet-)$, MT $=$ minimum tillage $(\neg-)$, and NT $=$ no-tillage $(\leftarrow \boldsymbol{\sim})$

the upper soil layer was not affected $(p<0.05)$ by tillage and $\mathrm{N}$ fertilization. Soil strength (soil penetration) of all tillage treatment increased with depth, but the increased of soil strength under IT at 50-60 cm depth was 39\% and 16\% higher than NT and MT, respectively (Figure 1; Table 2). It indicated that long-term IT could induce soil compaction at $50-60 \mathrm{~cm}$ depth. Similar results were reported by Dickey et al. (1994) and Singh and Kaur (2012).

\section{Soil Moisture and Soil Temperature}

Soil moisture and soil temperature were measured during vegetative growth of soybean (2010) at 0-5 cm depth. Tillage system was the only treatment that significantly affected $(\mathrm{p}<0.05)$ soil moisture and soil temperature. It turned out that soil moisture under NT was significantly higher $(\mathrm{p}<0.05)$ than IT, but not significantly different from MT (Table 2). The higher of soil moisture under CT (NT and MT) compared to IT was in agreement with those reported by Blevins et al. (1983), Diaz-Zorita et al. (2004), and Singh and Kaur (2012). This was attributable to the effect of plant residues left on soil surface with respect of $\mathrm{CT}$ that could reduce 
Tabel 2. Soil moisture, soil temperature and soil strength after 23 years of cropping (1987-2010) as affected by tillage systems and $\mathrm{N}$ fertilization.

\begin{tabular}{lccc}
\hline Tillage treatments & $\begin{array}{l}\text { Soil moisture }(\%) \text { at } 0- \\
5 \mathrm{~cm} \text { depth }\end{array}$ & $\begin{array}{l}\text { Soil temperature }\left({ }^{\circ} \mathrm{C}\right) \text { at } 0- \\
5 \mathrm{~cm} \text { depth }\end{array}$ & $\begin{array}{l}\text { Soil strength }(\mathrm{kPa}) \text { at } 50- \\
60 \mathrm{~cm} \text { depth }\end{array}$ \\
\hline Intensive tillage & $16.0 \mathrm{a}$ & $28.8 \mathrm{a}$ & $710 \mathrm{c}$ \\
Minimum tillage & $22.1 \mathrm{~b}$ & $30.0 \mathrm{~b}$ & $610 \mathrm{~b}$ \\
No-tillage & $22.0 \mathrm{~b}$ & $30.1 \mathrm{~b}$ & $510 \mathrm{a}$ \\
\hline
\end{tabular}

Values within a column followed by the same letter are not significantly different at 0.05 level.

water evaporation resulted in higher soil moisture content (Blevins et al. 1983; Utomo 2004). Strong effect of CT on soil moisture was also related to higher soil organic matter under this long-term CT soil (Utomo et al. 2010; Utomo et al. 2012). Mallory et al. (2011) confirmed that greater water storage in no-till soils can be attributed to the larger percentages of meso-pores and macro-pore continuity.

Soil temperature under NT in temperate region was usually lower than that of IT (Blevins and Frye, 1993; Rasmussen, 1999; Singh and Kaur, 2012). Difference from those findings, however, soil temperature at $0-5 \mathrm{~cm}$ under NT or MT in this experiment (tropical environment) was significantly higher $(p<0.05)$ than soil temperature under IT (Table 2). Even though the presence of mulch in NT could potentially heating the heat to a greater depth, thus increased soil moisture (Table 3), but at $0-5 \mathrm{~cm}$ depth, the heat received by mulched NT tended to offset the cooling effect of evaporation with respect of NT.

\section{Soil pH and Total Nitrogen}

Soil $\mathrm{pH}$ is among important factors that can influence soil chemical characteristics and crop yields (Brady and Weil, 2008). Similar to those reported by Kumar and Yadav (2005), soil pH at all depths was not affected by tillage treatment and its interaction with $\mathrm{N}$ fertilization, but was affected by $\mathrm{N}$ fertilization except for $20-40 \mathrm{~cm}$ depth (Table 3). Less acidification effect of CT in this experiment was attributed to stronger buffering capacity with respect to CT. However, this finding was difference from those reported by Blevins and Frye (1993), Karlen et al. (1994) and Utomo et al. (2010) that soil pH under CT at surface layer was lower than IT.

Regardless the tillage system, soil $\mathrm{pH}$ at $0-5$ $\mathrm{cm}$ depth was lower than that of 10-20 cm depth and soil $\mathrm{pH}$ under long-term $\mathrm{CT}$ tended to be higher than IT across the soil profile (Figure 2). Even though soil $\mathrm{pH}$ was not affected by long-term tillage, but refer to soil $\mathrm{pH}$ at reference site (Table 1), it indicated that in long-term crop production, any tillage had similar acidifying effect particularly just few $\mathrm{cm}$ at the upper soil layer.

As those reported by Blevins et al (1977) and Barak et al (1997), soil pH in this long-term experiment (after 23 years of cropping) was decreased $(\mathrm{p}<0.05)$ with increasing $\mathrm{N}$ rate. Soil $\mathrm{pH}$ with rate of $200 \mathrm{~kg} \mathrm{~N} \mathrm{ha}^{-1}$ at $0-10 \mathrm{~cm}$ depths was $7 \%$ lower $(\mathrm{p}<0.5)$ than that with no $\mathrm{N}$ fertilizer, and even $11 \%$ lower $(p<0.05)$ at $10-20 \mathrm{~cm}$ depth (Table $3)$. This was attributed to an acidifying effect of $\mathrm{N}$ fertilizer (urea) that could decrease soil $\mathrm{pH}$ as shown in this reaction (Havlin et al. 2005):

$\left(\mathrm{NH}_{2}\right)_{2} \mathrm{CO}+4 \mathrm{O}_{2} \rightarrow 2 \mathrm{NO}_{3}^{-}+2 \mathrm{H}^{+}+\mathrm{CO}_{2}+\mathrm{H}_{2} \mathrm{O}$ Hydrolysis and nitrification of urea as an acid forming fertilizer in well-drained soil will induce soil acidity (Barak et al. 1997). This is an indication that long-term nitrogen fertilization has stronger acidification effect than long-term tillage systems. Refer to reference site (Table 1), long-term N

Table 3. Soil $\mathrm{pH}$ after 23 years of cropping (1987-2010) as affected by $\mathrm{N}$ fertilization at $0-40 \mathrm{~cm}$ depth.

\begin{tabular}{lcccc}
\hline \multirow{2}{*}{ N rate $\left(\mathrm{kg} \mathrm{N} \mathrm{ha}^{-1}\right)$} & \multicolumn{4}{c}{ Soil pH } \\
\cline { 2 - 5 } & $0-5 \mathrm{~cm}$ & $5-10 \mathrm{~cm}$ & $10-20 \mathrm{~cm}$ & $20-40 \mathrm{~cm}$ \\
\hline 0 & $5.93 \mathrm{~b}$ & $6.13 \mathrm{~b}$ & $6.31 \mathrm{~b}$ & $5.99 \mathrm{a}$ \\
25 or 100 & $5.92 \mathrm{~b}$ & $6.15 \mathrm{~b}$ & --- & --- \\
50 or 200 & $5.54 \mathrm{a}$ & $5.70 \mathrm{a}$ & $5.67 \mathrm{a}$ & $5.58 \mathrm{a}$ \\
\hline \hline
\end{tabular}

Values within a column followed by the same letter are not significantly different at 0.05 level 


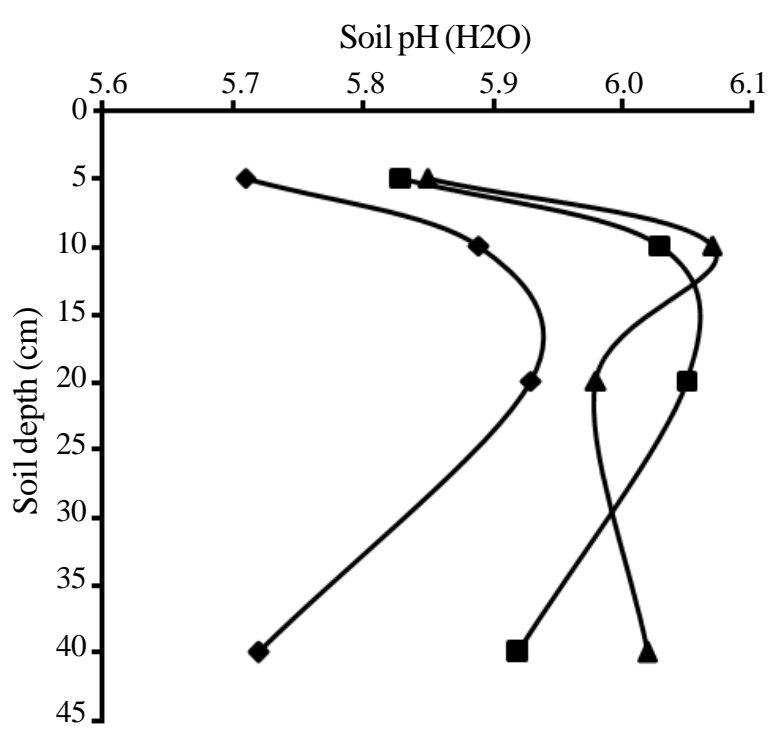

Figure 2. Soil $\mathrm{pH}$ profile after 23 years of cropping (1987-2010) as affected by tillage systems at $0-40 \mathrm{~cm}$ depth; intensive tillage $(\multimap-)$, minimum tillage $(\longrightarrow-)$, and no-tillage (ㄴ)

fertilization could reduce soil $\mathrm{pH}$ at the upper soil layer.

Total soil nitrogen is integral component of many essential plant compounds such as amino acids, chlorophyll and carbohydrate (Brady and Weil, 2008). At 5-10 cm depth, total $\mathrm{N}$ under MT was higher $(p<0.05)$ than NT, but there were no different than IT (Table 4). Although plant residues from NT was returned back on to the soil surface, but due to $\mathrm{N}$ mineralization from plant residue probably could not exceed the higher $\mathrm{N}$ uptake, resulted in less total soil $\mathrm{N}$ with respect to NT. This finding was difference from those reported by Zibilske $e t$ al. (2002) and Brito-Vega et al. (2009).

Table 4. Total soil nitrogen after 23 years of cropping (1987-2010) as affected by tillage systems and $\mathrm{N}$ fertilization at $0-20 \mathrm{~cm}$ depth.

\begin{tabular}{llcc}
\hline \multirow{2}{*}{ Treatments } & \multicolumn{3}{c}{ Total N (\%) } \\
\cline { 2 - 4 } & $0-5 \mathrm{~cm}$ & $5-10 \mathrm{~cm}$ & $10-20 \mathrm{~cm}$ \\
\hline Intensive tillage & $0.17 \mathrm{a}$ & $0.16 \mathrm{ab}$ & $0.14 \mathrm{a}$ \\
Minimum tillage & $0.18 \mathrm{a}$ & $0.17 \mathrm{~b}$ & $0.14 \mathrm{a}$ \\
No-tillage & $0.16 \mathrm{a}$ & $0.14 \mathrm{a}$ & $0.14 \mathrm{a}$ \\
$0 \mathrm{~kg} \mathrm{~N} \mathrm{ha}^{-1}$ & $0.16 \mathrm{a}$ & $0.14 \mathrm{a}$ & $0.14 \mathrm{ab}$ \\
$25(100) \mathrm{kg} \mathrm{N} \mathrm{ha}^{-1}$ & $0.17 \mathrm{ab}$ & $0.16 \mathrm{ab}$ & $0.13 \mathrm{a}$ \\
$50(200) \mathrm{kg} \mathrm{N} \mathrm{ha}^{-1}$ & $0.19 \mathrm{~b}$ & $0.18 \mathrm{~b}$ & $0.16 \mathrm{~b}$ \\
\hline
\end{tabular}

Values within a column followed by the same letter are not significantly different at 0.05 level.
Table 5. Exchangeable $\mathrm{K}$ and $\mathrm{Ca}$ after 23 years of cropping (1987-2010) as affected by interaction of tillage systems and $\mathrm{N}$ fertilization.

\begin{tabular}{llclc}
\hline Treatment & \multicolumn{2}{c}{$\mathrm{K}$} & & $\underline{\mathrm{Ca}}$ \\
\cline { 2 - 3 } combinations & $0-5 \mathrm{~cm}$ & $5-10 \mathrm{~cm}$ & & $0-5 \mathrm{~cm}$ \\
\hline Intensive tillage: & $\ldots \ldots \ldots \ldots$ & $\left(\mathrm{Cmole} \mathrm{kg}^{-1}\right)$ & $\ldots \ldots \ldots \ldots$ \\
$0 \mathrm{~kg} \mathrm{~N} \mathrm{ha}^{-1}$ & $0.48 \mathrm{ab}$ & $0.39 \mathrm{ab}$ & & $6.13 \mathrm{ab}$ \\
$25(100) \mathrm{kg} \mathrm{N} \mathrm{ha}^{-1}$ & $0.28 \mathrm{a}$ & $0.21 \mathrm{a}$ & & $5.71 \mathrm{ab}$ \\
$50(200) \mathrm{kg} \mathrm{N} \mathrm{ha}^{-1}$ & $0.31 \mathrm{ab}$ & $0.22 \mathrm{a}$ & $6.20 \mathrm{ab}$ \\
Minimum tillage: & & & \\
$0 \mathrm{~kg} \mathrm{~N} \mathrm{ha}^{-1}$ & $0.75 \mathrm{~b}$ & $0.70 \mathrm{~b}$ & & $7.40 \mathrm{~b}$ \\
$25(100) \mathrm{kg} \mathrm{N} \mathrm{ha}^{-1}$ & $0.62 \mathrm{~b}$ & $0.57 \mathrm{~b}$ & $6.89 \mathrm{ab}$ \\
$50(200) \mathrm{kg} \mathrm{N} \mathrm{ha}^{-1}$ & $0.38 \mathrm{ab}$ & $0.34 \mathrm{ab}$ & $5.38 \mathrm{a}$ \\
No-tillage: & & & \\
$0 \mathrm{~kg} \mathrm{~N} \mathrm{ha}$ & & $0.55 \mathrm{~b}$ & $0.50 \mathrm{~b}$ & $6.51 \mathrm{ab}$ \\
$25(100) \mathrm{kg} \mathrm{N} \mathrm{ha}^{-1}$ & $0.58 \mathrm{~b}$ & $0.51 \mathrm{~b}$ & $6.75 \mathrm{ab}$ \\
$50(200) \mathrm{kg} \mathrm{N} \mathrm{ha}^{-1}$ & $0.60 \mathrm{~b}$ & $0.45 \mathrm{ab}$ & $6.60 \mathrm{ab}$ \\
\hline
\end{tabular}

Values within a column followed by the same letter are not significantly different at 0.05 level.

In this long-term experiment, strong influence of $\mathrm{N}$ fertilization on total soil $\mathrm{N}$ was more pronounce than tillage treatment. Total soil $\mathrm{N}$ due to higher $\mathrm{N}$ rate of all depths were significantly higher $(\mathrm{p}<0.05)$ than without $\mathrm{N}$. This was attributed to the fact that not all $\mathrm{N}$ from $\mathrm{N}$ fertilizer was taken up by crops, but some was left in the soil due to immobilized by microbe. Referring to initial total soil $\mathrm{N}$ content of reference site (Table 1), higher $\mathrm{N}$ rate fertilization could induce more total soil $\mathrm{N}$ left within $0-10 \mathrm{~cm}$ depth of the soil.

This important finding indicated that long-term higher $\mathrm{N}$ fertilization rate has residual effect on total soil $\mathrm{N}$ within the $0-20 \mathrm{~cm}$ depth. Greater retention of $\mathrm{N}$ fertilizer due to $\mathrm{N}$ immobilization may improve crop $\mathrm{N}$ use efficiency by subsequent remineralization of the $\mathrm{N}$ in better synchrony with crop need (Utomo et al. 1989; Zibilske et al. 2002).

\section{Exchangeable Potassium and Calcium}

Potassium and calcium are important nutrients needed for plant growth. One of readily available forms of these important nutrients for plant growth is an exchangeable base (Brady and Weil 2008).

Table 5 showed that with medium $\mathrm{N}$ rate, exchangeable $\mathrm{K}$ under $\mathrm{CT}$ at $0-5 \mathrm{~cm}$ depth was $114 \%$ higher $(\mathrm{p}<0.05)$ than that of IT, while at 5-10 $\mathrm{cm}$ depths was $157 \%$ higher $(\mathrm{p}<0.05)$. At depth of 10-20 cm however, there was no interaction effect of tillage and $\mathrm{N}$ fertilization. Exchangeable $\mathrm{K}$ for NT was similar to MT in this depth, it was $114 \%$ higher $(\mathrm{p}<0.05)$ than IT. As that of decreasing soil 
$\mathrm{pH}$ due to $\mathrm{N}$ fertilization (Table 3 ), exchangeable $\mathrm{K}$ also decreased with increasing $\mathrm{N}$ rate. Exchangeable $\mathrm{K}$ for high $\mathrm{N}$ rate in this depth was not different from medium $\mathrm{N}$ rate, but it was $48 \%$ lower $(\mathrm{p}<0.05)$ than without $\mathrm{N}$ fertilization.

At $0-5 \mathrm{~cm}$ depth, exchangeable $\mathrm{Ca}$ for combination of MT and no $\mathrm{N}$ fertilization was the highest among other combination, while combination with higher $\mathrm{N}$ rate was the lowest (Table 5). Values of exchangeable $\mathrm{Ca}$ for MT at 5-10 cm and 10-20 $\mathrm{cm}$ depth were no different from that of NT, but it was $15 \%$ higher $(\mathrm{p}<0.05)$ than IT. As that of exchangeable $\mathrm{K}$, exchangeable $\mathrm{Ca}$ at $10-20 \mathrm{~cm}$ depth was reduced by $\mathrm{N}$ fertilization as much as was $9 \%$. The strong effect of CT on exchangeable bases was associated with decomposition of plant residues with respect to CT. However, these findings were not in agreement with research result from Kentucky that reported by Blevins and Frye (1993).

\section{Microbial Biomass Carbon}

Microbial biomass $\mathrm{C}$ was measured at before planting, vegetative growth and after harvest of corn season in 2011. Microbial biomass $C$ under NT was consistently higher $(p<0.05)$ than IT along the corn season, while it was no significantly different $(p<0.05)$ between NT and MT (Table 6). Contrast to reported by Utomo et al (2010), however, microbial biomass $C$ in this season was not affected $(p<0.05)$ by nitrogen fertilization. Strong effect of $\mathrm{CT}$ on microbial biomass $\mathrm{C}$ was probably attributable to the effect of surface residue and less soil disturbance. Shift from high to low soil disturbance such as conventional tillage to no-tillage, often promotes the accumulation of otherwise labile soil organic carbon that is less available to microbial attack, controls carbon decomposition rates and increases total microbial biomass (Paustian et al.1997; Six et al. 2006; Utomo et al. 2010). As

Table 6. Soil microbial biomass carbon after 24 years of cropping (1987-2011) as affected by tillage systems at $0-20 \mathrm{~cm}$ depth.

\begin{tabular}{|c|c|c|c|}
\hline \multirow[b]{2}{*}{ Treatments } & \multicolumn{3}{|c|}{ Soil Microbial Biomass C } \\
\hline & $\begin{array}{l}\text { Before } \\
\text { planting }\end{array}$ & $\begin{array}{l}\text { Vegetative } \\
\text { growth }\end{array}$ & $\begin{array}{l}\text { After } \\
\text { harvest }\end{array}$ \\
\hline & \multicolumn{3}{|c|}{$\ldots \ldots \ldots \ldots\left(\mathrm{kg} \mathrm{CO}_{2}-\mathrm{C}\right.$ day $\left.^{1}\right) \ldots \ldots \ldots \ldots$} \\
\hline $\begin{array}{l}\text { Intensive } \\
\text { tillage }\end{array}$ & $57.7 \mathrm{a}$ & $120.3 \mathrm{a}$ & $163.6 \mathrm{a}$ \\
\hline $\begin{array}{l}\text { Minimum } \\
\text { tillage }\end{array}$ & $60.6 \mathrm{ab}$ & $133.9 \mathrm{ab}$ & $176.6 \mathrm{~b}$ \\
\hline No-tillage & $64.4 \mathrm{~b}$ & $142.3 \mathrm{~b}$ & $184.3 \mathrm{~b}$ \\
\hline
\end{tabular}

Values within a column followed by the same letter are not significantly different at 0.05 level. labile component of soil organic $\mathrm{C}$, soil microorganisms can contribute to microbial biomass C (Wang et al.2001).

\section{Soil Morphological Characteristics}

Representative soil pedons were selected only on plot of long-term tillage systems combined with highest $\mathrm{N}$ rate. It turned out that after 24 years of cropping (1987-2011), there were different soil morphological characteristics among tillage systems (Table 7). After 24 years of cropping, CT had deeper top soil layer than IT. The depth of Ap horizon under MT plot was the deepest, while the Ap under IT plot was the shallowest one (Table 8). With plant residue and slightly tilled, MT had better micro climate that could accelerate more biological tillage effect, resulted on much deeper Ap horizon.

Among the soil morphological characteristics, soil color of the tillage system was the most distinct one. The Munsell soil color chart of tillage treatments in Ap horizon ranged from 5YR 2.5/2 to 5YR 3/3, while in A/B horizon was similar (5YR 3/4). Value and chroma notation of no-tillage in Ap horizon was the lowest among other tillage treatments, while in intensive tillage was the highest. Slightly darker of no-tillage Ap horizon was attributed to the higher organic $\mathrm{C}$ in upper soil layer with respect to NT as those reported by previous researchers (Wright and Hons 2004; Al-Kaisi and Yin 2005; Blanco-Canqui and Lal 2008; Utomo et al. 2012).

Other soil morphological characteristics in this study were size of soil structure type and amount of macro pores. Soil structure size changed from fine sub angular blocky under IT to medium sub angular blocky under CT (MT or NT), while amount of macro pores changed from few under IT to many under CT (Table 7). The larger size of sub angular blocky under CT than IT soil indicated the better soil aggregation due to the lower surface soil disturbance with respect to CT. This condition also reflected on the larger macro pores occurred under long-term CT soil, which mostly formed from earthworm borrow (Derpch 1998; Utomo et al. 2010). This macro pores which connected to soil surface are important for aeration and drainage (Utomo et al. 2010). The better soil aggregation with respect of CT was in accordance with that reported by Edwards et al. (1988).

\section{Soybean and Corn Yields}

After 23 years of cropping (2010), soybean yields for MT and NT were $71.4 \%$ and $57.1 \%$ higher $(\mathrm{p}<0.05)$ than IT, respectively. While in corn season (2011), corn yield for MT was similar to NT, and it 
Table 7. Soil morphological characteristics after 24 years of cropping (1987-2011) as affected by tillage systems and nitrogen fertilization.

\begin{tabular}{|c|c|c|c|c|c|}
\hline $\begin{array}{l}\text { Tillage } \\
\text { treatments }\end{array}$ & Horizon & $\begin{array}{l}\text { Depth } \\
\text { (cm) }\end{array}$ & Soil color & Soil structure & Macro pores \\
\hline \multirow[t]{3}{*}{ Intensive tillage } & $\overline{A p}$ & $0-13$ & $5 \mathrm{YR} 3 / 3$ & $\begin{array}{l}\text { Subangular blocky, } \\
\text { fine }\end{array}$ & Few \\
\hline & $\mathrm{A} / \mathrm{B}$ & $13-30$ & $2.5 \mathrm{YR} 4 / 6$ & $\begin{array}{l}\text { Subangular blocky, } \\
\text { medium }\end{array}$ & Few \\
\hline & $\mathrm{Bt}$ & $30+$ & $\begin{array}{l}\text { Not } \\
\text { determined }\end{array}$ & $\begin{array}{l}\text { Not } \\
\text { determined }\end{array}$ & Not determined \\
\hline \multirow[t]{3}{*}{ Minimum tillage } & Ap & $0-18$ & $5 \mathrm{YR} 3 / 2$ & $\begin{array}{l}\text { Subangular blocky, } \\
\text { medium }\end{array}$ & Many \\
\hline & $\mathrm{A} / \mathrm{B}$ & $18-33$ & $2.5 \mathrm{YR} 4 / 4$ & $\begin{array}{l}\text { Subangular blocky, } \\
\text { medium }\end{array}$ & Few \\
\hline & $\mathrm{Bt}$ & $33+$ & $\begin{array}{l}\text { Not } \\
\text { determined }\end{array}$ & $\begin{array}{l}\text { Not } \\
\text { determined }\end{array}$ & Not determined \\
\hline \multirow[t]{3}{*}{ No-tillage } & Ap & $1.5-17$ & $5 \mathrm{YR} 3 / 2$ & $\begin{array}{l}\text { Subangular blocky, } \\
\text { medium }\end{array}$ & Many \\
\hline & $\mathrm{A} / \mathrm{B}$ & $17-28$ & $5 Y R 3 / 4$ & $\begin{array}{l}\text { Subangular blocky, } \\
\text { medium }\end{array}$ & Few \\
\hline & $\mathrm{Bt}$ & $28+$ & $\begin{array}{l}\text { Not } \\
\text { determined }\end{array}$ & $\begin{array}{l}\text { Not } \\
\text { determined }\end{array}$ & Not determined \\
\hline
\end{tabular}

was $31.8 \%$ higher $(\mathrm{p}<0.05)$ than that of IT (Table $8)$. Strong responses of soybean and corn to CT which just observed after 23 years of cropping were attributed to the better soil properties under longterm continuous CT application (Tables 2, 4-7). This was also contributed by strong mulching effect with respect to CT, resulted in a higher nutrient uptake and crop yield (Lal 1989; Utomo et al. 1989; Fengyun et al. 2011).

As a legume, soybean had no response to $\mathrm{N}$ fertilization. Soybean yield for N rate of $25 \mathrm{~kg} \mathrm{~N}$ ha $^{-1}$ was $1.9 \mathrm{Mg} \mathrm{ha}^{-1}$ or only $5 \%$ lower than $\mathrm{N}$ rates of 0 or $50 \mathrm{~kg} \mathrm{~N} \mathrm{ha}^{-1}$. On the other hand, as a cereal crop, corn had strong response to $\mathrm{N}$ fertilization. Corn yield for 100 and $200 \mathrm{~kg} \mathrm{~N} \mathrm{ha}^{-1}$ were $36.4 \%$

Table 8 . Soybean and corn yields as affected by long-term tillage systems and $\mathrm{N}$ fertilization.

\begin{tabular}{lcc}
\hline Treatments & Soybean, 2010 & Corn, 2011 \\
\hline & $\ldots \ldots\left(\mathrm{Mg} \mathrm{ha}^{-1}\right) \ldots \ldots$ \\
Intensive tillage & $1.4 \mathrm{a}$ & $4.4 \mathrm{a}$ \\
Minimum tillage & $2.4 \mathrm{~b}$ & $5.8 \mathrm{~b}$ \\
No-tillage & $2.2 \mathrm{~b}$ & $5.8 \mathrm{~b}$ \\
$0 \mathrm{~kg} \mathrm{~N} \mathrm{ha}^{-1}$ & $2.0 \mathrm{a}$ & $4.4 \mathrm{a}$ \\
$25(100) \mathrm{kg} \mathrm{N} \mathrm{ha}^{-1}$ & $1.9 \mathrm{a}$ & $6.0 \mathrm{~b}$ \\
$50(200) \mathrm{kg} \mathrm{N} \mathrm{ha}^{-1}$ & $2.0 \mathrm{a}$ & $5.5 \mathrm{~b}$ \\
\hline
\end{tabular}

Values within a column followed by the same letter are not significantly different at 0.05 level and $25.0 \%$ higher $(\mathrm{p}<0.05)$ than with no $\mathrm{N}$ fertilization, respectively (Table 8 ). These findings were in agreement with those reported by Dickey et al. (1994) and Fengyun et al. (2011).

\section{CONCLUSIONS}

Although the soil surfaces were continuously not tilled for 24 years, but the bulk density and soil porosity of conservation tillage (CT) at $0-10 \mathrm{~cm}$ depth were still no different from intensive tillage (IT). Soil strength tended to increase with depth, but at depth of 50-60 cm the soil strength under IT was $28.2 \%$ and $26.4 \%$ higher than no-tillage (NT) and minimum tillage (MT), respectively. Soil moisture and soil temperature under CT $(\mathrm{MT}=\mathrm{NT})$ at $0-5$ $\mathrm{cm}$ depth were respectively $38.1 \%$ and $4.5 \%$ higher than IT.

Soil $\mathrm{pH}$ after 23 years of cropping was not affected by tillage, but decreased with increasing $\mathrm{N}$ rate up to $20 \mathrm{~cm}$ depth. Compared to no $\mathrm{N}$ fertilization, long-term high $\mathrm{N}$ rate decreased soil $\mathrm{pH}$ at $0-20 \mathrm{~cm}$ depth as much as $10 \%$ and increased total soil $\mathrm{N}$ at $0-5 \mathrm{~cm}$ depth as much as $19 \%$. At 0 $10 \mathrm{~cm}$ depth, MT with no N fertilization had highest exchangeable $\mathrm{K}$, in contrast, IT with medium $\mathrm{N}$ rate application had the lowest. At $0-5 \mathrm{~cm}$ depth, MT with no $\mathrm{N}$ fertilization had highest exchangeable $\mathrm{Ca}$, however, with higher $\mathrm{N}$ rate, MT had the lowest. Microbial biomass $\mathrm{C}$ throughout the growing season 
under long-term NT was consistently highest among other tillage systems, and it was $14.4 \%$ higher than IT.

There were different soil morphological characteristics among long-term tillage systems. After 24 years of cropping, Ap horizon of CT (MT and NT) was deeper and darker than IT. Soil structure size changed from fine sub angular blocky under IT to medium sub angular blocky under CT, while amount of macro pores changed from few under IT to many under CT.

Soybean and corn had strong responses to long-term tillage systems. After 23 to 24 years of cropping, soybean and corn yields for CT (MT=NT) were $64.3 \%$ and $31.8 \%$ higher than IT, respectively. Different from soybean, corn had strong response to $\mathrm{N}$ fertilization. Corn yield with 100 and $200 \mathrm{~kg} \mathrm{~N}$ ha $^{-1}$ were respectively $36.4 \%$ and $25.0 \%$ higher than with no $\mathrm{N}$ fertilization.

\section{ACKNOWLEDGEMENTS}

Our deeply acknowledgement is being delivered to Directorate General of Higher Education, Ministry of National Education Republic of Indonesia for supporting this research through Hibah Kompetitif Penelitian Sesuai Prioritas Nasional in 2009-2011. Our highly appreciation is also delivered to University of Lampung for their never ending supports and Politeknik Negeri Lampung for their permission of the long-term experiment plots.

\section{REFERENCES}

Al-Kaisi and X Yin. 2005. Tillage and crop residue effects on soil carbon dioxide emission in corn- soybean rotation. J Environ Qual 34: 437-445. Pub Med.

Barak P, BO Jobe, AR Krueger, LA Peterson and DA Laird. 1997. Effects of long-term soilacidification due to nitrogen inputs in Wisconsin. Plant Soil 197: 61-69.

Blake GR and KH Hartge. 1986. Bulk density. In: A Klute (ed). Methods of Soil Analysis. ASA and SSSA. Madison, Wisconsin, USA, pp. 363-375.

Blanco-Canqui H and R Lal. 2008. No-till and soil-profile carbon sequestration: an on farm assessment. Soil Sci Soc Am J 72: 693-701.

Blanco-Canqui H, LR Stone and PW Stahlman. 2010. Soil response to long-term cropping systems on an Argiustoll in the Central Great Plains. Soil Sci Soc Am J74: 602-611.

Blevins RL, MS Smith, GW Thomas and WW Frye. 1983. Influence of conservation tillage on soil properties. J Soil Water Conserv 38: 301-305.
Blevins RL, GW Thomas and PL Cornelius. 1977 Influence of no-tillage and nitrogen fertilization on certain soil properties after 5 years of continuous corn. Agron J 69: 383-386.

Blevins, RL and WF Frye, 1993. Conservation tillage: an ecological approach to soil management. Adv Agron 51:34-77.

Brady NC and RR Weil. 2008. The nature and properties of soils. Pearson Prentice Hall. Fourteenth Edition. New Jersey, $965 \mathrm{p}$.

Brito-Vega, H, D Espinosa-Victoria, C Fragoso, D Mendoza, N De la Cruz Landaro and A AldaresChavez. 2009. Soil organic particle and presence of earthworm under different tillage systems. J Biol Sci 9: $180-183$.

Derpch, R 1998. Historical review of no-tilage cultivation of crops. JIRCAS Working Rep. JAPAN Int Res Ctr for Agric Sciences, Ibaraki, Japan 13: 1-18.

Diaz-Zorita, M., JH Grove, L Murdock, J Herbeck and E Perfect. 2004. Soil structural disturbance effects on crop yields and soil properties in a no-till production system. Agron J 96: 1651-1659.

Dickey EC, PJ Jasa and RD Grisso. 1994. Long-term tillage effect on grain yield and soil properties in a soybean/ grain sorghum Rotation. J Prod Agric 7: 465 - 470.

Edwards WM, LD, Norton, CE, Redmond. 1988. Characterizing macro pores that affect infiltration into non tilled soil. Soil Sci Soc Am J 52: 483-487.

Fernandez RO, PG Fernandez, JVG Cervera and FP Torres. 2007 Soil properties and crop yields after 21 years of direct drilling trials in southern Spain. Soil Till Res 94: 47-54.

Fengyun Z, W Pute, Z Xining and C Xuefeng. 2011. The effects of no-tillage practice on soil physical properties. Afr J Biotech 10: 17645-17650.

Havlin, JL, JD Beaton, SM Tisdale and WL Nelson. 2005. Soil Fertility and Fertilizer: an Introduction to Nutrient Management. Pearson Prantice Hall. Sevent Edition. Upper Saddle River, New Jersey, 515 p.

Karlen DL, NC Wollenhaupt, DC Erbach, EC Berry, JB Swan, NS Eash and JL Jordahl. 1994. Crop residue effects on soil quality following 10-years of no-till corn. Soil Till Res 31: 149-167.

Kumar A and DS Yadav. 2005. Effect of zero and minimum tillage in conjunction with nitrogen management in wheat (Triticum aestivum) after rice (Oryza sativa.). Indian J Agron 50 (1): 54-57.

Lal R. 1989. Conservation tillage for sustainable agriculture: tropics versus temper-ate environment. Adv Agron 42: 85-197.

Lal R. 1997. Residue management, conservation tillage and soil restoration for mitigating greenhouse effect by $\mathrm{CO}_{2}$ enrichment. Soil Till Res 43: 81-107.

Lal R. 2007. Soil science in a changing climate. CSA New 52: 1-9.

Mallory J J, RH Mohtar, GC Heathman, DG Schulze and E Braudeau. 2011. Evaluating the effect of tillage on soil structural properties using the pedostructure concept. Geoderma 163: 141-149. doi:10.1016/ j.geoderma. 2011.01.018.9p. 
Paustian K, HP Collins and EA Paul. 1997. Management control on soil carbon. In: EA Paul, ET Elliot, K Paustian and CV Cole (eds). Soil Organic Matter in Temperate Agro-ecosystems: Long-term Experiment in North America. CRC Press, pp.15-50.

Rasmussen, KJ. 1999. Impact of ploughless soil tillage on yield and soil quality: A Scandinavian review. Soil Till Res 53: 3-14.

Quintero M. 2009. Effects of conservation tillage in soil carbon sequestration and net revenues of potatobased rotations in the Colombian Andes. [Thesis], University of Florida, USA.

SAS [Statistical Analysis System] Institute. 2003. The SAS system for windows. Release 9.1. SASInst Inc, Cary, NC.

Singh A and J Kaur. 2012. Impact of conservation tillage on soil properties in rice-wheat cropping system. Agric Sci Res J 2: 30-41.

Six, J, SD Frey, RK Thiet and KM Batten. 2006. Bacterial and fungal contributions to carbon sequestration in agroecosystems. Soil Sci Soc Am J 70: 555-569.

Smith JL and HP Collins. 2007. Management of organisms and their processes in soils. In: EA Paul (ed). Soil Microbiology, Ecology and Biochemistry. Third Edition. Academic Press, Burlington, USA, 532 p.

Stockfisch N, T Forstreuter, W Ehlers. 1999. Ploughing effects on soil organic matter after twenty years of conservation tillage in Lower Saxony, Germany. Soil Till Res 52: 91-101.

Tarkalson, DD, GW Hergertb and KG Cassmanc. 2006. Long-term effects of tillage on soil chemical properties and grain yields of a dryland winter wheatsorghum/corn-fallow rotation in the great plains. Agron J 26: 26-33.
Thomas GA, RC Dalal, J Standley. 2007. No-till effect on organic matter, $\mathrm{pH}$, cation exchange capacity and nutrient distribution in a Luvisol in the semi-arid subtropics. Soil Till Res 94: 295-304.

Utomo M, H Suprapto and Sunyoto. 1989. Influence of tillage and nitrogen fertilization on soil nitrogen, decomposition of alang-alang (Imperata cylindrica) and corn production of alang-alang land. In: J van der Heide (ed.). Nutrient management for food crop production in tropical farming systems. Institute for Soil Fertility (IB), pp. 367-373.

Utomo M. 2004. Olah tanah konservasi untuk budidaya jagung berkelanjutan. Prosiding Seminar Nasional IX Budidaya Pertanian Olah Tanah Konservasi. Gorontalo, 6-7 Oktober, 2004, pp.18-35 (in Indonesian).

Utomo M, A Niswati, Dermiyati, M R Wati, AF Raguan and S Syarif. 2010. Earthworm and soil carbon sequestration after twenty one years of continuous no-tillage corn-legume rotation in Indonesia. JIFS 7:51-58.

Utomo M, H Buchari, IS Banuwa, LK Fernando and R Saleh. 2012. Carbon storage and carbon dioxide emission as influenced by long-term conservation tillage and nitrogen fertilization in corn-soybean rotation. J Trop Soil 17: 75-84.

Wang W, RC Dalal and PW Moody. 2001. Evaluation of the microwave irradiation method for measuring soil microbial biomass. Soil Sci Soc Am J 65: 1696-1703.

Wright AL and FM Hons. 2004. Soil aggregation and carbon and nitrogen storage under soybean cropping sequences. Soil Sci Soc Am J 68: 507-513.

Zibilske LM, JM Bradford and JR Smart. 2002. Conservation tillage induced change in organic carbon, total nitrogen and available phosphorus in a semi-arid alkaline subtropical soil. Soil Till Res 66: 153-163. 